\title{
Comparison of the genexpert enterovirus assay (GXEA) with real-time one step RT-PCR for the detection of enteroviral RNA in the cerebrospinal fluid of patients with meningitis
}

JiYoung Hong ${ }^{1,3}$, Ahyoun Kim¹, Seoyeon Hwang ${ }^{1}$, Doo-Sung Cheon', Jong-Hyen Kim², June-Woo Lee ${ }^{1 *}$, Jae-Hak Park ${ }^{3}$ and Byunghak Kang ${ }^{1 *}$

\begin{abstract}
Background: Enteroviruses (EVs) are the leading cause of aseptic meningitis worldwide. Detection of enteroviral RNA in clinical specimens has been demonstrated to improve the management of patient care, especially that of neonates and young children.

Findings: To establish a sensitive and reliable assay for routine laboratory diagnosis, we compared the sensitivity and specificity of the GeneXpert Enterovirus Assay (GXEA) with that of the reverse transcription polymerase chain reaction (RT-PCR) based assay referred to as real-time one step RT-PCR (RTo-PCR). The sensitivity/specificity produced by GXEA and RTo-PCR were $100 \% / 100 \%$ and $65 \% / 100 \%$, respectively.

Conclusions: Both methods evaluated in this article can be used for detection of enterovirus in clinical specimens and these nucleic acid amplification methods are useful assays for the diagnosis of enteroviral infection.
\end{abstract}

Keywords: GeneXpert Enterovirus Assay, Real-time one step reverse transcription polymerase chain reaction, Enteroviruses, Cerebrospinal fluid

\section{Findings}

Enteroviruses (EVs) are the most common cause of aseptic meningitis in children and adults and may cause up to $90 \%$ of aseptic meningitis cases [1]. The rapid and accurate diagnosis of human enteroviral infections can reduce the use of antibiotics, duration of hospitalization, and financial costs [2-6]. Methods involving the amplification of nucleic acids have replaced traditional culturebased methods as the gold standard for the detection of EVs in cerebrospinal fluid (CSF) because of their increased sensitivity and speed. Routine diagnostic methods using real-time reverse transcription polymerase chain reaction (RT-PCR) have been developed over the past 15 years in an attempt to improve experts' ability to detect EVs in CSF [7]. The latest development in

\footnotetext{
* Correspondence: junewoo1213@korea.kr; bh4400@daum.net

'Division of Vaccine Research, Center for Infectious Diseases, National Institute of Health, Korea Center for Disease Control and Prevention, Cheongju, Republic of Korea

Full list of author information is available at the end of the article
}

the diagnosis of enteroviral meningitis is the GeneXpert Enterovirus Assay (GXEA; Cepheid, Sunnyvale, CA), a fully automated real-time multiplex RT-PCR assay. GXEA is the only assay approved by the U.S. Food and Drug Administration for the qualitative detection of enteroviral RNA in CSF. The GeneXpert system is a closed, unitdose, molecular, microfluidics instrument that performs extraction, processing, and real-time RT-PCR, as well as the detection of nucleic acid targets. The system uses single-use cartridges that contain all of the reagents required for sample processing and PCR [8-10].

We compared the speed and reliability of GXEA with that of real-time one step RT-PCR (RTo-PCR), a method described in a previous publication by Verstrepen et al., that is routinely used for the detection of enteroviral RNA in CSF [11].

To determine the detection range of RTo-PCR using a TaqMan-formatted probe, we obtained five reference strains belonging to different serotypes (enterovirus 71, 
coxsackievirus B2, echovirus 30, coxsackievirus A24, and poliovirus 1) from the American Type Culture Collection (ATCC) and used these strains to determine the detection limit and positive control of RTo-PCR.

To assess the applicability of GXEA to detect EVs in clinical specimens with a low viral load, from June to September of 2008, we collected 109 CSF specimens from patients with aseptic meningitis. We had approval of an Institutional Review Board (IRB) through the Korean National Institute of Health. We analyzed these specimens by GXEA according to the manufacturer's instructions using $140 \mu \mathrm{L}$ of each sample. For the RToPCR assay, viral RNA was extracted using silica-coated magnetic beads based on Boom's method in combination with an automatic liquid handling machine (TECAN, Männedorf, Switzerland) [12]. The TaqMan format RTo-PCR for the detection of EVs was performed according to the previously optimized reaction conditions [11]. Both assays targeted the $5^{\prime}$ noncoding region of the EV genome, which is commonly used in routine diagnostic assays because of its highly conserved genetic identity $[11,13]$.

GXEA and RTo-PCR detected the presence of enterovirus in test samples from five reference strains, of different serotypes, with the limits of detection ranging from 2 to $0.05 \mathrm{TCID}_{50} / \mathrm{mL}$ for GXEA and from 1 to 0.01 $\mathrm{TCID}_{50} / \mathrm{mL}$ for RTo-PCR (data not shown). Next, we compared the detection efficiency of the recently developed GXEA molecular diagnostic system, which is based on the concept of a "lab on a chip," with that of RToPCR, using the CSF samples collected in 2008 from patients with meningitis. Of the 109 clinical samples assayed by GXEA and RTo-PCR, 66 and 43 were determined to be positive, respectively (Table 1). All of the samples found to be positive by RTo-PCR were also detected by GXEA, with no false positives. In the detection of enteroviral RNA from CSF, the sensitivities/specificities of RTo-PCR and GXEA were 65\%/100\% and 100\%/ $100 \%$, respectively. The GXEA results were in agreement with those produced by RTo-PCR in $78.9 \%$ of cases.

To compare the detection efficiencies of the assays used in this study, we used the mean $\mathrm{Ct}$ values from the positive samples; specifically, we divided the values from the GXEA-positive samples by those from the RToPCR-positive samples, and the values from the GXEA-

Table 1 Results of RTo-PCR assay and GXEA for 109 clinical samples from patients with aseptic meningitis

\begin{tabular}{|c|c|c|}
\hline & $\begin{array}{l}\text { No. of positive results/ } \\
\text { total no. of samples }\end{array}$ & $\begin{array}{l}\text { No. of negative results/ } \\
\text { total no. of samples }\end{array}$ \\
\hline$\overline{\text { GXEA }^{a}}$ & $66 / 109$ & $43 / 109$ \\
\hline RTo-PCR assay $^{b}$ & $43 / 109$ & $66 / 109$ \\
\hline
\end{tabular}

${ }^{a}$ GeneXpert Enterovirus Assay.

${ }^{b}$ Real-time one step RT-PCR. positive samples by those from the RTo-PCR-negative samples (Figure 1). The mean $\mathrm{Ct}$ values from the GXEAand RTo-PCR-positive samples (GXEA(+)/TaqMan $(+))$ and those from the GXEA-positive, RTo-PCR-negative samples $(\operatorname{GXEA}(+) / \operatorname{TaqMan}(-))$ were 32.38 and 34.85 , respectively. According to our results, GXEA is more sensitive than RTo-PCR. This can be explained by the distribution of the $\mathrm{Ct}$ values for the positive specimens, which is an indirect measure of the viral load, as shown in Figure 1.

The sensitivity of GXEA was higher than that of RToPCR, and GXEA did not produce discordant positive results when conduced on the RTo-PCR-positive specimens. The mean $\mathrm{Ct}$ values for the GXEA-only positive samples $(\operatorname{GXEA}(+) / \operatorname{TaqMan}(-))$ were about 2.5 fold higher than those for the samples found to be positive by both assays $(\operatorname{GXEA}(+) / \operatorname{TaqMan}(+))$; thus, GXEA is at least 10 times more sensitive than routine RTo-PCR. The discrepancy observed in this study amomg the

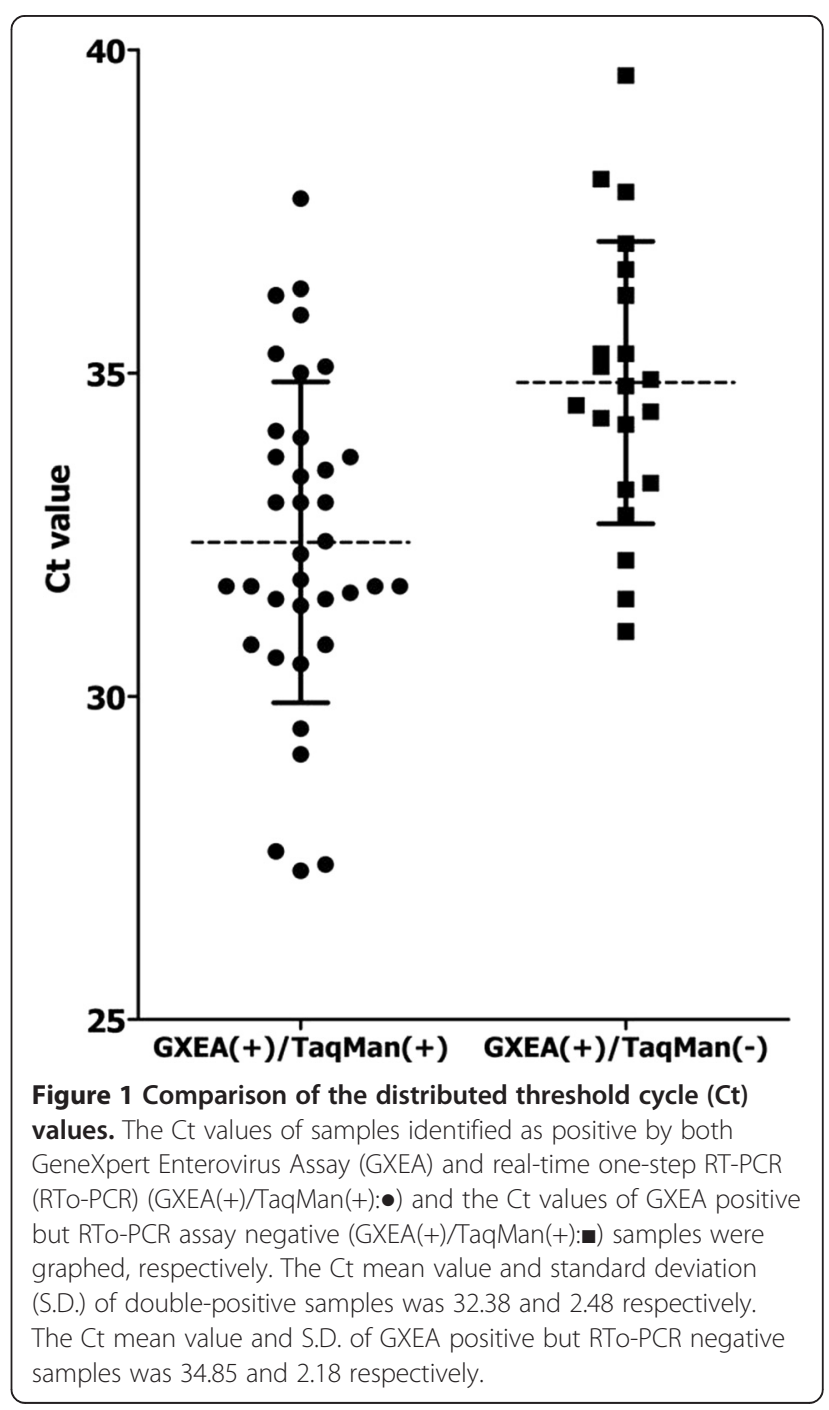


qualitative results for the CSF samples with a low viral load $(n=20)$ indicates a higher than expected incidence of CSF specimens from patients with viral meningitis with viral titers below the detection limit of routine molecular assays. Evidently, qualitative tests for the detection of EVs can be influenced by the detection limit of the molecular assay being used.

The GXEA system produced a lower $\mathrm{Ct}$ value than RTo-PCR. This may be explained by the fact that GXEA utilizes single-use cartridges that contain all of the reagents required for sample processing. Thus, the entire amount of extracted RNA is used in GXEA, while, in RTo-PCR, the amount of RNA used may be 10 -fold lower. The sensitivity of an assay depends in part on the total amount of RNA used.

\section{Viruses, controls, and clinical samples}

Five reference strains belonging to distinct genotypes [enterovirus 71 (E71), coxsackievirus B2 (CVB2), echo 30 (E30), coxsackievirus A24 (CVA24), and poliovirus type 1 (P1)] were obtained from the American Type Culture Collection (ATCC). Infectivity of viruses was assayed by microplates in serial 10-fold dilutions (from $10^{-4}$ to $10^{-10}$ ) in quadruplicate (four wells per dilution). $\mathrm{TCID}_{50}$ titers were calculated according to the Kärber method [14]. In total, 109 clinical specimens were collected from patients with suspected viral meningitis between June and September 2008.

\section{Extraction of viral RNA}

RNA was extracted from $150 \mu \mathrm{L}$ samples with the GM Viral Nucleic Acid Extraction Kit (GreenMate Biotech Corp, Korea), according to the manufacturer's protocol, using automated machines for liquid handling (Tecan, Switzerland). The GM Viral Nucleic Acid Extraction Kit uses a silica-based extraction method [12]. RNA was then recovered in $50 \mu \mathrm{L}$ of nuclease-free water. It was used immediately or stored at $-70^{\circ} \mathrm{C}$.

\section{One-step real-time RT-PCR}

Real-time one step RT-PCR (RTo-PCR) was performed using an ABI Prism 7900HT sequence detection system (Applied Biosystems). Viral RNA was amplified in $25 \mu \mathrm{L}$ reactions using RT-PCR master mix (AgPath-ID onestep RT-PCR Kit; Ambion, CA). Reactions were incubated at $45^{\circ} \mathrm{C}$ for $15 \mathrm{~min}$, and then at $95^{\circ} \mathrm{C}$ for $10 \mathrm{~min}$, followed by 45 cycles of $95^{\circ} \mathrm{C}$ for $15 \mathrm{~s}$ and $60^{\circ} \mathrm{C}$ for $40 \mathrm{~s}$.

Viral nucleic acid amplification is being developed as a diagnostic procedure to detect enteroviral infections [15]. There is an urgent need to devise standardized methods, utilizing commercialized kits, that can supplement or replace the diagnostic tests that are often developed in-house, and that are, therefore, inconsistent in their sensitivity and specificity. The GeneXpert machine and assay kit, which has been approved by the U.S. Food and Drug Administration for the detection of EVs, produces rapid and highly sensitive results from CSF samples $[9,10]$.

These innovative tests, based on state-of-the-art technologies, provide the means by which to achieve more accurate clinical laboratory results and, therefore, better patient care, when attempting to diagnose or rule out sepsis.

\section{Abbreviations}

EVs: Enteroviruses; GXEA: GeneXpert enterovirus assay; RTo-PCR: Real-time one step RT-PCR; CSF: Cerebrospinal fluid; IRB: Institutional review board; E71: Enterovirus 71; CVB2: Coxsackievirus B2; E30: Echo virus 30; CVA24: Coxsackievirus A24; P1: Poliovirus type 1; ATCC: American type culture collection.

\section{Competing interests}

The authors declare that they have no competing interests.

\section{Authors' contributions}

JYH, AYK, and SYH performed molecular biology experiments. JHK, DSC and JHP drafted the manuscript. JYH contributed to specimen collection and clinical diagnosis. JYH, JWL and BHK designed the study and meticulously revised the manuscript to ensure scientific accuracy. All of the authors read and approved the final version of the manuscript.

\section{Acknowledgments}

This study was supported by an intramural research fund (project 4859300) from the National Institute of Health, Korea.

\section{Author details}

${ }^{1}$ Division of Vaccine Research, Center for Infectious Diseases, National Institute of Health, Korea Center for Disease Control and Prevention, Cheongju, Republic of Korea. ${ }^{2}$ Department of Pediatrics, Catholic University College of Medicine, Suwon, Republic of Korea. ${ }^{3}$ Department of Laboratory Animal Medicine, College of Veterinary Medicine, Seoul National University, Seoul, Republic of Korea.

Received: 7 May 2014 Accepted: 2 February 2015

Published online: 13 February 2015

\section{References}

1. Abzug MJ. Presentation, diagnosis, and management of enterovirus infections in neonates. Paediatr Drugs. 2004;6:1-10.

2. Ginocchio CC, Zhang F, Malhotra A, Manji R, Sillekens $P$, Foolen $H$, et al. Development, technical performance, and clinical evaluation of a Nuclisens basic kit application for detection of enterovirus RNA in cerebrospinal fluid. J Clin Microbiol. 2005:43:2612-23.

3. King RL, Lorch SA, Cohen DM, Hodinka RL, Cohn KA, Shah SS. Routine cerebrospinal fluid enterovirus polymerase chain reaction testing reduces hospitalization and antibiotic use for infants 90 days of age or younger. Pediatrics. 2007;120:489-96.

4. Nolts FS. Case studies in cost effectiveness of molecular diagnostic for infectious diseases: pulmonary tuberculosis, enteroviral meningitis, and BK virus nephropathy. Clin Infect Dis. 2006;43:1463-7.

5. Parasuraman TV, Frenia K, Remero J. Enteroviral meningitis: cost of illness and considerations for the economic evaluation of potential therapies. Pharmacoeconomics. 2001;19:3-12.

6. Ramers C, Billman G, Hartin M, Ho S, Sawyer MH. Impact of a diagnostic cerebrospinal fluid enterovirus polymerase chain reaction test on patient management. JAMA. 2000;283:2680-5.

7. Nijhuis M, Van Maarseveen N, Schuurman R, Verkuijlen S, De Vos M, Hendriksen $\mathrm{K}$, et al. Rapid and sensitive routine detection of all members of the genus enterovirus in different clinical specimens by real-time PCR. J Clin Microbiol. 2002;40:3666-70.

8. Kost CB, Rogers B, Oberste MS, Robinson C, Eaves BL, Leos K, et al. Multicenter beta trial of the GeneXpert enterovirus assay. J Clin Microbiol. 2007;45:1081-6. 
9. Marlowe EM, Novak SM, Dunn JJ, Smith A, Cumpio J, Makalintal E, et al. Performance of the GeneXpert enterovirus assay for detection of enteroviral RNA in cerebrospinal fluid. J Clin Virol. 2008:43:110-3.

10. Seme K, Mocilnik T, Komlos KF, Doplihar A, Persing DH, Poljak M. GeneXpert enterovirus assay: one-year experience in a routine laboratory setting and evaluation on three proficiency panels. J Clin Microbiol. 2008;46:1510-3.

11. Verstrepen WA, Bruynseels $P$, Mertens AH. Evaluation of a rapid real-time RT-PCR assay for detection of enterovirus RNA in cerebrospinal fluid specimens. J Clin Viral. 2002;25(S1):S39-43.

12. Aertsens M, De Canniere P, Moors H. Modelling of silica diffusion experiments with 32Si in Boom Clay. J Contam Hydrol. 2003;61(1-4):117-29.

13. Rotbart HA. Diagnosis of enteroviral meningitis with the polymerase chain reaction. J Pediatr. 1990;117:85-9.

14. Cary J. Assays for virus infection. In: Cann AJ, editor. A practical approach series, virus culture. New York: Oxford University Press; 1999. p. 83-4.

15. Dierssen U, Rehren F, Henke-Gendo C, Harste G, Heim A. Rapid routine detection of enterovirus RNA in cerebrospinal fluid by one-step real time RT-PCR assay". J Clin Virol. 2008;42:58-64.

\section{Submit your next manuscript to BioMed Central and take full advantage of:}

- Convenient online submission

- Thorough peer review

- No space constraints or color figure charges

- Immediate publication on acceptance

- Inclusion in PubMed, CAS, Scopus and Google Scholar

- Research which is freely available for redistribution 